\title{
Germination and growth of the tree Handroanthus chrysanthus (Bignoniaceae) under nursery conditions
}

\author{
Henry Hernan Medina Arroyo ${ }^{1}$ (D), Jhon Jerley Torres-Torres² (iD), Carlos Alexis Palacios Palacios ${ }^{3}$ (iD), \\ Bayron Alexander Ruiz-Blandón ${ }^{4}$ (D), Melida Martínez Guardia ${ }^{5}$ (D) \& Leyser Rengifo Murillo 6 (iD) \\ 1. Choco University of Technology, Engineering Faculty. Agroforestry Engineering Program. A. A. 292 B/ Nicolás \\ Medrano, Quibdó, Colombia; d-henry.hernan@utch.edu.co \\ 2. Animal Science and Agroforestry Resources Research Group. Engineering Faculty. Choco University of Technology. \\ Quibdó, Colombia; i-jhon.torres@utch.edu.co \\ 3. Planning Advisory Office, Villa Rica, Cauca, Colombia; alexis1017008@gmail.com; \\ 4. Department of Botany and Zoology. University Center of Biological and Agricultural Sciences, University of \\ Guadalajara (UdeG). Zapopan, Jalisco, México; toxbombaso@yahoo.es; \\ 5. Engineering Faculty. Agroforestry Engineering Program. Choco University of Technology. Quibdo, Colombia; \\ melidamaguar@yahoo.es \\ 6. Production Systems Research Group. Engineering Faculty. Choco University of Technology. Quibdo, Colombia; \\ leyserregifo123@gmail.com
}

Recibido 23-III-2020 • Corregido 13-VII-2020 • Aceptado 22-VII-2020 DOI: https://doi.org/10.22458/urj.v12vi2.3175

\begin{abstract}
Introduction: Selective logging of forests has significantly diminished the densities of Handroanthus chrysantha Jacq. in Colombia. Therefore, there is a need for studies that contribute to its management. Objective: We aimed to evaluate seed germination and the growth of seedlings under nursery conditions. Methods: Four pregerminative, four organic substrates and two luminosity conditions were tested. We used a random multifactorial experimental design composed of 32 controlled factors. The main components were immersion of seeds in water at room temperature at different times, combinations of organic substrates and exposure of the factors to shade and sun. Results: We recorded 395 and 290 germinated seeds, corresponding to 51 and $38 \%$ of the total sown under shade and sun, respectively. The factors with the best germination values were immersion for 24 hours with alluvial sand and immersion for 24 hours with river sand of mixed with ant soil (2:1) under shade and, without immersion with alluvial sand+ground of ant 2:1 and immersion for 24 hours with chicken manure+ant soil 2:1 under sun. The highest growth in height, vigour and survival was observed in seedlings exposed to full sunlight in any of the combinations of organic substrates. Conclusion: The propagation of $H$. chrysantha should germinate the seeds under shadow and then expose them to the sun to stimulate their growth.
\end{abstract}

Keywords: Yellow Guayacan, pre-germination, propagation, seedling survival, organic substrates.
RESUMEN. "Germinación y crecimiento del árbol Handroanthus chrysantha (Bignoniaceae) en condiciones de vivero". Introducción: La tala selectiva de los bosques ha reducido las densidades de Handroanthu chrysantha Jacq. en Colombia, por lo que se hace necesarios estudios que aporten a su manejo. Objetivo: Evaluar la germinación de las semillas y el crecimiento de las plántulas de $H$. chrysantha en vivero. Metodología: Probamos cuatro tratamientos pre-germinativos, cuatro sustratos orgánicos y dos condiciones de luminosidad. Se utilizó un diseño experimental multifactorial aleatorizado integrado por 32 factores controlados. Los componentes principales fueron: inmersión de semillas en agua a temperatura ambiente en diferentes horas, combinaciones de diferentes sustratos orgánicos y exposición de los factores a sombra y sol. Resultados: Registramos 395 y 290 semillas germinadas, que corresponden al 51 y $38 \%$ del total sembrado bajo sombra y sol, respectivamente. Los factores con mejor germinación fueron inmersión por 24 horas con arena aluvial e inmersión por 24 horas con arena de río+tierra de hormiga 2:1 bajo sombra y, sin inmersión con arena aluvial+tierra de hormiga 2:1 e inmersión por 24 horas con gallinaza+tierra de hormiga 2:1 en sol. Los mejores resultados en altura, vigor y supervivencia fueron de plántulas expuestas a plena luz solar en cualquiera de las combinaciones de sustratos orgánicos utilizados. Conclusión: Para la propagación de $H$. chrysantha se deben germinar las semillas en sombra y después exponerlas al sol para estimular su crecimiento.

Palabras clave: Guayacán amarillo, pre-germinativos, propagación, supervivencia de plántulas, sustratos orgánicos. 
The biogeographic Choco is one of the most biodiverse places on the planet (Torres-Torres, Mena, \& Álvarez, 2016; Torres-Torres, Mena, \& Álvarez, 2017). Its forests have the highest number of species and communities per unit of area, 300 species in 0,1ha in zonal vegetation (Mosquera, Medina, \& Martínez, 2012; Palacios, Perea, Bedillo, Caicedo, \& Abadia, 2017; Mena, Andrade, \& Torres-Torres, 2020). Its floristic variety, endemism and the threat to its natural resources make it one of the planet's biodiversity hotspots (Myers, Mittermeiner, Mittermeiner, De Fonseca, \& Kent, 2000).

Anthropic activities such as conversion of forest land to agricultural and livestock uses, mining extraction and unplanned harvesting of forest resources by local communities have led to the reduction of populations of forest species such as Handroanthus chrysantha Jacq., currently categorized as Critically Endangered (CE) (Blaser \& Thompson, 2010). The specimens of this species registered in the department of Choco are scarce (78 individuals), and $60 \%$ of them are in the upper diameter classes (Klínger et al., 2011). This situation is compounded by the fact that at the local level few alternatives have been undertaken to contribute to the sustainability of this species in the forest ecosystems of this state; furthermore, at the regional level, information regarding its germination, growth and initial adaptation to different organic substrates and pre-germination treatments is limited, making it difficult to manage.

Based on the above, Martínez, Torres-Torres, and Medina (2015) suggest that this situation requires environmental authorities to exercise control over activities that deteriorate forest ecosystems and restrict their conservation and protection. Therefore, it is vitally important to develop studies of the behavior of forest species in nurseries that guarantee the obtaining of the necessary plant material for their subsequent establishment in the forests, as an alternative to mitigate the damage caused and contribute to the restoration of the composition and structure of the forest.

In the search for alternatives to recover and conserve threatened forest species of socioecological importance, the use of organic substrates such as alluvial sand, forest soil, ant soil, leaf litter and rice husk has been proposed (Trujillo, 1995; Pinilla et al., 2016; Torres-Torres, Medina, \& Martínez, 2018b). Similarly, mechanical scarification and immersion of seeds in water at different temperatures and for different periods of time are recommended as pre-germination treatments (Torres-Torres, Medina, Pinilla, Córdoba \& Martínez, 2017; Torres-Torres, Medina, \& Martínez, 2018a; 2018c).

Therefore, the purpose of this research was to evaluate the effect of four pre-germination treatments and organic substrates on the germination and initial growth of $H$. chrysantha. This was done under two environmental conditions (free sun exposure and under shade), seeking to obtain as much information as possible to contribute to the propagation strategies of this species.

\section{MATERIALS AND METHODS}

Area of study: The investigation was carried out in the town of Salero, municipality of Unión Panamericana, Choco, Colombia $\left(5^{\circ} 20^{\prime} 07,5^{\prime \prime} \mathrm{N} \& 76^{\circ} 37^{\prime} 30^{\prime \prime} \mathrm{W}\right)$. This place is characterized by an average temperature of $28^{\circ} \mathrm{C}$, rainfall of $10000 \mathrm{~mm}, 90 \%$ relative humidity and an altitude of 100masl (Alcaldía de Unión Panamericana, 2016).

Experimental design: A multi-factorial, randomized experimental design, consisting of 32 controlled factors, was used. The main components were four immersion times, four organic substrates in different combinations and proportions, and two lighting conditions (Table 1). 
Installation of the experiment: A 15 square meter nursery was built, consisting of two $1,10 \mathrm{~m} \times 4 \mathrm{~m}$ germination beds, raised to one meter above the ground. The wood was immunized with cypermentine. The aerial part of the infrastructure was covered with translucent polypropylene plastic. The first set of factors was placed inside, $20 \mathrm{~m}$ away from the nursery, a germination bed was built with the same dimensions as the previous ones, where the second set of factors was established at full sun exposure.

Origin and sowing of the seeds: The seeds used were obtained from commercial houses and were sown in seedbeds. Each factor was composed of twelve replicates. Four seeds were sown per cell. This was done at a depth of $1 \mathrm{~cm}$. Two factors were placed randomly in each seedbed and identified with a legend or sign. The factors were spatially distributed identically in each light condition: sun and shade. A total of 1536 seeds were used, distributed in 32 factors.

Monitoring of the experiment: The germination of the seeds was quantified every eight days, during one month. When the seedlings reached a height of $5 \mathrm{~cm}$, they were transplanted in their entirety into $1 \mathrm{~kg}$ black polyethylene bags, with the same substrates used initially.

TABLE 1

Pre-germination, organic substrates and combination of controlled factors used in the germination and initial growth of $H$. chrysantha under sun and shade conditions.

\begin{tabular}{|c|c|c|c|c|c|}
\hline \multirow{2}{*}{$\begin{array}{l}\text { Pre-germination treatments } \\
A(\text { witness): non-immersion }\end{array}$} & \multirow{2}{*}{$\begin{array}{l}\text { Organic substrates } \\
E \text { (witness): Alluvial sand }\end{array}$} & \multicolumn{4}{|c|}{ Controlled factors } \\
\hline & & $\mathrm{AE}$ & $\mathrm{BE}$ & CE & $\mathrm{DE}$ \\
\hline B: Water immersion for 24 hours & F: Chicken manure+ alluvial sand + ant soil 1:1:1 & AF & $\mathrm{BF}$ & $\mathrm{CF}$ & DF \\
\hline C: Water immersion for 36 hours & G: Chicken manure+ ant land 2:1 & AG & BG & CG & DG \\
\hline D: Water immersion for 48 hours & $\mathrm{H}$ : Alluvial sand + ant soil 2:1 & $\mathrm{AH}$ & $\mathrm{BH}$ & $\mathrm{CH}$ & $\mathrm{DH}$ \\
\hline
\end{tabular}

Variables evaluated and form of measurement: The evaluation of the variables of growth in height of the seedlings and survival was initiated 30 days after the transplant to the polyethylene bags. For the evaluation of these variables, $22 \%$ of the planted material was used (10 seedlings per factor). Survival was estimated using the following equation (Rivera, Peñuela, Jiménez, \& Vargas, 2013):

$$
\text { Survival }=\frac{\text { Number of live plants }}{\text { Total number of plants transplanted }} * 100 \quad \text { Equation } 1
$$

These variables were measured every 15 days for three months. All seedlings were given two daily risks and monitored to detect and avoid any affectation.

Data analysis: The statistical analysis was carried out using the STATGRAPHISCS version 5.1 software. A multifactorial $4 \times 4 \times 2$ design with 12 repetitions was applied, which is described by the following mathematical model:

$$
y_{i j k l}=\mu+\tau_{i}+\beta_{j}+\gamma_{k}+(\tau \beta)_{i j}+(\tau \gamma)_{i k}+(\beta \gamma)_{j k}+(\tau \beta \gamma)_{i j k}+\varepsilon_{i j k l} \quad \text { Equation } 2
$$

Where: $\boldsymbol{y}_{\boldsymbol{i} \boldsymbol{j} \boldsymbol{k} \boldsymbol{l}}$ is the growth of the seedlings in $\mathrm{cm} ; \boldsymbol{\mu}$ is the overall average growth of the seedlings; $\boldsymbol{\tau}_{\boldsymbol{i}}$ is the simple effect of the pre-sprouting; $\boldsymbol{\beta}_{\boldsymbol{j}}$ is the simple effect of the type of organic substrate; $\boldsymbol{\gamma}_{\boldsymbol{k}}$ is the simple effect of the light condition; $(\boldsymbol{\tau} \boldsymbol{\beta})_{\boldsymbol{i}}$ is the effect of interaction between 
pre-sprouting and light condition; $(\boldsymbol{\tau} \boldsymbol{\beta} \gamma)_{\boldsymbol{i j k}}$ is the effect of interaction between type of organic substrate and light condition; $\boldsymbol{\varepsilon}_{\boldsymbol{i} \boldsymbol{j} \boldsymbol{k} \boldsymbol{l}}$ is the mistake.

An analysis of multifactorial variance (ANOVA) with a significance level of $\alpha=0,05$ and a $95 \%$ reliability was performed to evaluate the efficiency of pre-germination and organic substrates and to identify the factors that favored the growth in heights of $H$. chrysantha seedlings. The analysis was supplemented by testing the minimal significant difference of Fisher's (LSD) with $95 \%$ confidence.

\section{RESULTS}

Germination: $H$. chrysantha, presented epigea germination. This began two days after sowing and ended 30 days after the seeds were sown.

At the end of the evaluation period, 395 and 290 germinated seeds were recorded, corresponding to 51 and $38 \%$ of the total sown under shade and sun, respectively (Table 2).

TABLE 2

Analysis of Variance (ANOVA) for seedling growth at heights of $H$. chrysantha.

\begin{tabular}{lccccc}
\hline \multicolumn{1}{c}{ Source } & $\begin{array}{c}\text { Sum of } \\
\text { Squares }\end{array}$ & $\begin{array}{c}\text { Degrees of } \\
\text { freedom }\end{array}$ & $\begin{array}{c}\text { Medium } \\
\text { Square }\end{array}$ & Reason - F & Value - ${ }^{-}$ \\
\hline Co-variable & 1018,88 & 1 & 1018,88 & 109,75 & 0,0000 \\
Days & & & & & \\
Main effects & 381,847 & 3 & 127,28 & 1,37 & 0,2547 \\
A: Pre-germination & 595,012 & 3 & 198,34 & 2,14 & 0,0989 \\
B: Substrate & 987,042 & 1 & 987,04 & 106,32 & 0,0001 \\
C: Lighting & & & & & \\
Interactions & 685,304 & 9 & 761,45 & 8,20 & 0,0000 \\
AB & 395,727 & 3 & 131,91 & 1,42 & 0,2398 \\
AC & 238,534 & 3 & 795,11 & 8,56 & 0,0000 \\
BC & 312,075 & 9 & 34,68 & 3,74 & 0,0003 \\
ABC & 1179,03 & 127 & 928,37 & & \\
Waste & 4558,12 & 159 & & & \\
Total & & & & & \\
\hline
\end{tabular}

Germination rates above $70 \%$ were obtained for seeds sown in the factors AE (no pregermination with alluvial sand), AH (no pre-germination with alluvial sand + ant soil 2:1), BE (24 hour water immersion with alluvial sand), BF (24 hour water immersion with chicken manure + alluvial sand + ant soil 1:1:1) and BH (24 hour water immersion with alluvial sand + ant soil 2: 1) under shaded conditions and, AG (no pre-germination with chicken manure + ant soil 2:1), AH (no pregermination with alluvial sand + ant soil 2:1), BE (24 hour water immersion with alluvial sand), BG (24 hours water immersion with chicken manure + ant soil 2:1) and BH (24 hour water immersion with alluvial sand + ant soil $2: 1$ ) in the sun respectively (Fig. 1). This result allows us to infer that in order to accelerate the germination of $H$. chrysantha, the seeds should be subjected to imbibition periods less than or equal to 24 hours.

In Fig. 1, it can be seen that in the majority of the factors with the presence of pregerminative B: (imbibition in water for 24 hours) the best results of germination were obtained. 


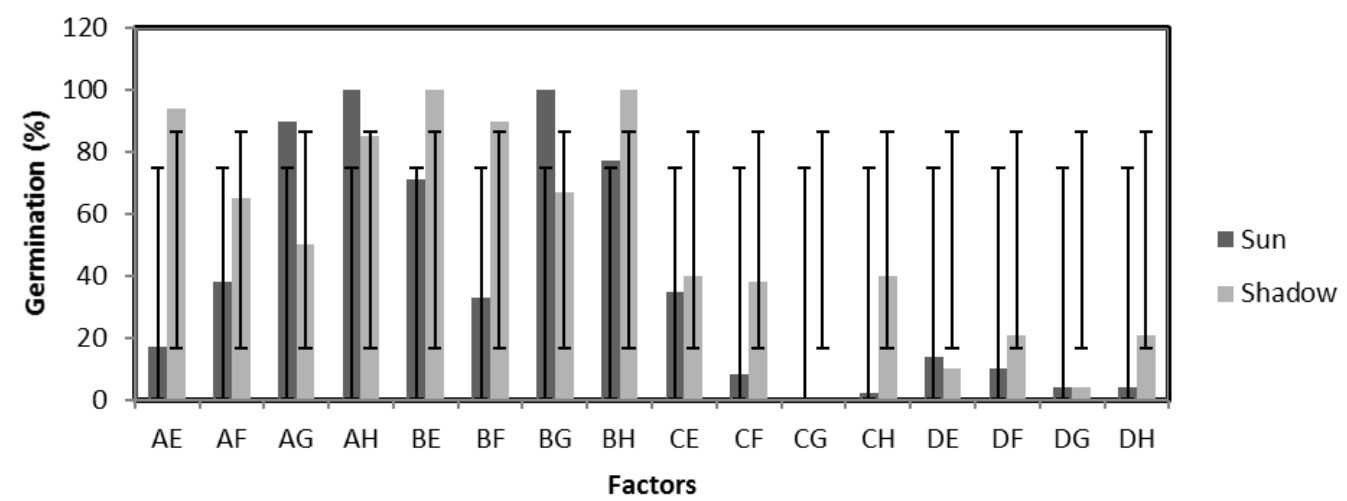

Fig. 1. Germination of seeds from H. chrysantha

AE: No Immersion and alluvial sand; AF: No Immersion and Chicken manure+alluvial sand+ant soil 1:1:1; AG: No Immersion and chicken manure+ ant land 2:1; AH: No Immersion and alluvial sand + ant soil 2:1; BE: Water immersion for 24 hours and alluvial sand; BF: Water immersion for 24 hours and Chicken manure+alluvial sand+ant soil 1:1:1; BG: Water immersion for 24 hours and chicken manure+ ant land 2:1; BH: Water immersion for 24 hours and alluvial sand + ant soil 2:1; CE: Water immersion for 36 hours and alluvial sand; CF: Water immersion for 36 hours and Chicken manure+alluvial sand+ant soil 1:1:1; CG: Water immersion for 36 hours and chicken manure+ ant land 2:1; CH: Water immersion for 36 hours and alluvial sand + ant soil 2:1; DE: Water immersion for 48 hours and alluvial sand; DF: Water immersion for 48 hours and Chicken manure+alluvial sand+ant soil 1:1:1; DG: Water immersion for 48 hours and chicken manure+ ant land 2:1; DH: Water immersion for 48 hours and alluvial sand + ant soil 2:1

Height growth: The results of the analysis of variance and Fisher's Minimal Significant Difference test $(p<0,05)$ indicate that there were significant statistical differences between the pregerminatives (effect A), nor between the substrates (effect B) used in this investigation (Table 2). Consequently, any of the combinations could be used for the growth of this forest species in the nursery.

When analyzing the interactions between the principal components, differences were detected between the principal effects $A B$ and $B C$; and triple interaction between the principal effects $A B C$ around the growth of the seedlings (Fisher, $p<0,05$ ) (Table 2 ).

Average growth values of 8 and $18 \mathrm{~cm}$ were obtained for seedlings located under shade and sun respectively (Table 2 ).

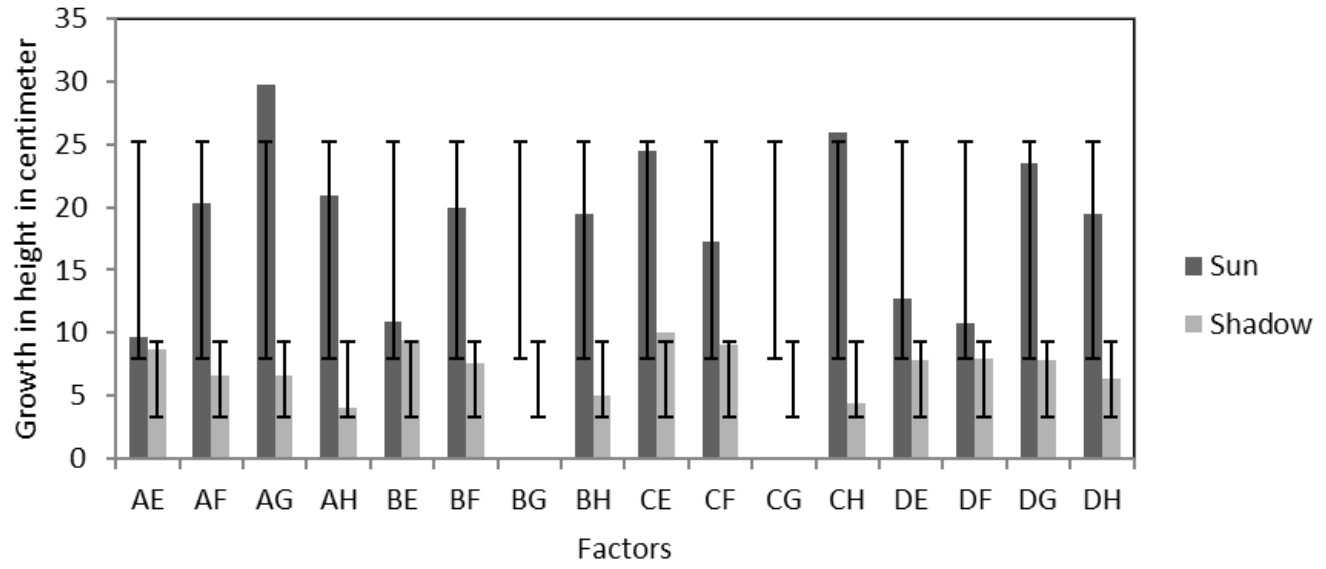

Fig. 2. Average growth in height $(\mathrm{cm})$ of $H$. chrysantha seedlings by light condition.

AE: No Immersion and alluvial sand; AF: No Immersion and Chicken manure+alluvial sand+ant soil 1:1:1; AG: No Immersion and chicken manure+ ant land 2:1; AH: No Immersion and alluvial sand + ant soil 2:1; BE: Water immersion for 24 hours and alluvial sand; BF: Water immersion for 24 hours and Chicken manure+alluvial sand+ant soil 1:1:1; BG: Water immersion for 24 hours and chicken manure+ ant land 2:1; BH: Water immersion for 24 hours and alluvial sand + ant soil 2:1; CE: Water immersion for 36 hours and alluvial sand; CF: Water immersion for 36 hours and Chicken manure+alluvial sand+ant soil 1:1:1; CG: Water immersion for 36 hours and chicken manure+ ant land 2:1; CH: Water immersion for 36 hours and alluvial sand + ant soil 2:1; DE: Water immersion for 48 hours and alluvial sand; DF: Water immersion for 48 hours and Chicken manure+alluvial sand+ant soil 1:1:1; DG: Water immersion for 48 hours and chicken manure+ ant land 2:1; DH: Water immersion for 48 hours and alluvial sand + ant soil 2:1 
Ten factors located at free sun exposure (AF, $A G, A H, B F, B G, B H, C E, C H, D G$ and $D H$ ) recorded growth values greater than $19 \mathrm{~cm}$ (Fig. 2).

Fisher's LSD test $(p<0,05)$ suggests that it is indifferent to use any type of substrate $(E, F, G$ or $\mathrm{H}$ ) in the growth of $H$. chrysantha seedlings as long as they receive direct radiation from the sun (Fig. 2). However, the yield is higher if the combination $\mathrm{H}$ (river sand + ant soil at 2:1) is used.

Survival: 270 of the 341 transplanted seedlings survived, corresponding to an overall percentage of $80,9 \%$. In addition, it was observed that the factors $\mathrm{BE}, \mathrm{BH} \mathrm{CF}, \mathrm{CH}, \mathrm{DF}, \mathrm{DG}$ and $\mathrm{DH}$ in sunny conditions and $A H, B H, E C, D E$ and $D G$ in the shade showed a high effectiveness in the survival of the seedlings with percentages of $100 \%$ (Fig. 3), not showing statistical differences between the factors evaluated. These results allow us to infer that any of the substrates used stimulate the survival of $H$. chrysantha.

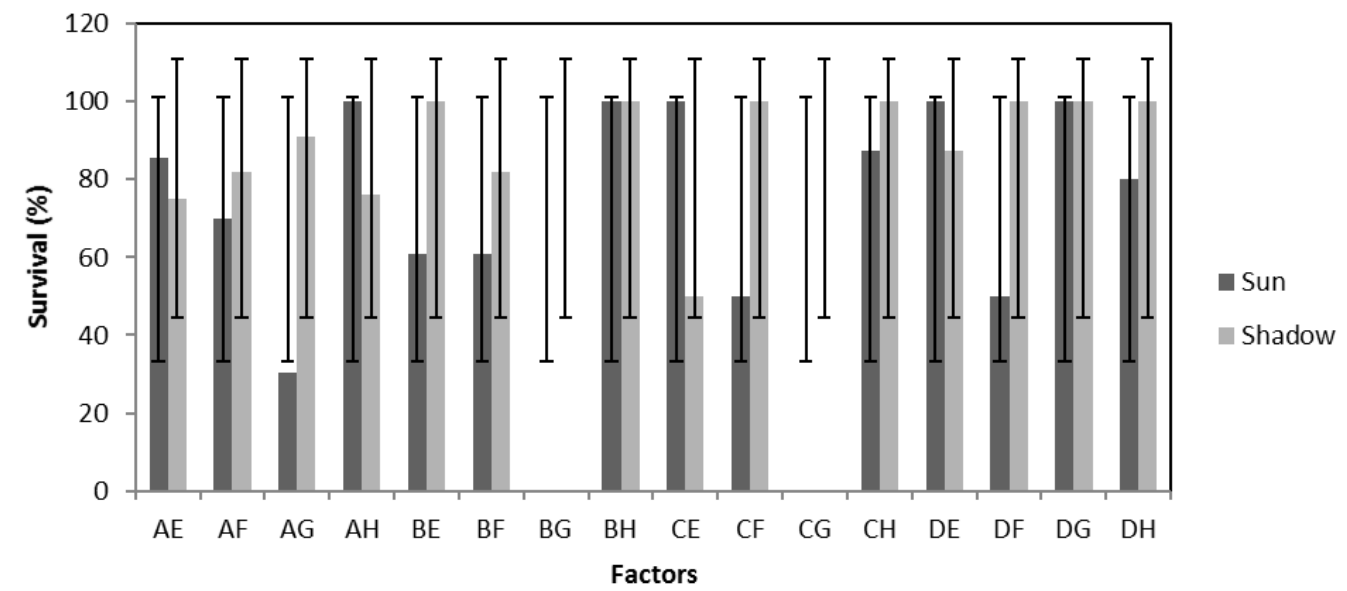

Fig. 3. Survival of $H$. chrysantha seedlings by light condition.

AE: No Immersion and alluvial sand; AF: No Immersion and Chicken manure+alluvial sand+ant soil 1:1:1; AG: No Immersion and chicken manure+ ant land 2:1; AH: No Immersion and alluvial sand + ant soil 2:1; BE: Water immersion for 24 hours and alluvial sand; BF: Water immersion for 24 hours and Chicken manure+alluvial sand+ant soil 1:1:1; BG: Water immersion for 24 hours and chicken manure+ ant land 2:1; BH: Water immersion for 24 hours and alluvial sand + ant soil 2:1; CE: Water immersion for 36 hours and alluvial sand; CF: Water immersion for 36 hours and Chicken manure+alluvial sand+ant soil 1:1:1; CG: Water immersion for 36 hours and chicken manure+ ant land 2:1; CH: Water immersion for 36 hours and alluvial sand + ant soil 2:1; DE: Water immersion for 48 hours and alluvial sand; DF: Water immersion for 48 hours and Chicken manure+alluvial sand+ant soil 1:1:1; DG: Water immersion for 48 hours and chicken manure+ ant land 2:1; DH: Water immersion for 48 hours and alluvial sand + ant soil 2:1

\section{DISCUSSION}

The type of germination observed in $H$. chrysantha is similar to those reported for other timber species in the Colombian Chocó Biogeographic (Pinilla et al., 2016; Rengifo \& Torres-Torres, 2016; Torres-Torres et al., 2017; Torres-Torres et al., 2018a; 2018b; 2018c). The time used for germination of seeds of the species under study differs from the results obtained by Cordero et al. (2003), who suggest that the germination process begins at seven days and extends to day 30 . This result can be related to the latency process acquired by the seeds before research and the environmental conditions of the site, so Varela and Arana (2011), add that, this feature is an adaptation that contributes to the survival of the individual, since it restricts germination when environmental factors are unfavorable to the development of the seedling.

The germination results obtained in this study (Fig. 1) were lower than those reported by Aguirre, Günter, and Stim (2008), who obtained values of 72,7 and $68 \%$ for seeds harvested from 
premature and mature fruits of the tree and from mature fruits of the soil, respectively. From this, it can be deduced that the fresher the seeds, the higher the percentage of germination.

The best records of germination were obtained in plant material sown in the shade (Fig. 1); this may be related to the process of moisture conservation that occurs in shaded places, which favors the appearance of the moisture needed for the emergence of soil cotyledons (Suarez \& Melgarejo, 2010; Torres-Torres et at., 2018c).

Varela and Arana (2011) mention that it is the physical, chemical and biological characteristics of the substrates that guarantees the germination of the seeds and the correct development of the seedling. The results of the research contrast with this statement, because it is observed that the organic substrates used (individually) do not influence the germination of the seeds of $H$. chrysantha, nor when combined with pre-germination.

STRI (2013) and Torres-Torres et al. (2018a) suggest that seed pre-treatments positively influence seed germination, especially in forest species growing in tropical rainforests. These indications are validated with the results obtained in this research

The growth values obtained in this study are similar to those suggested by Román, De Liones, Sautu, Deago, and Hall (2012), who report growths of 19 to $30 \mathrm{~cm}$ in four months in free sun exposure, allowing this to infer that $H$. chrysantha requires direct light for its initial growth.

According to Cordero et al. (2003) and Román et al. (2012), the greatest growth of $\mathrm{H}$. chrysantha is experienced in soils with little fertility and good drainage; this has been validated in the results of the present investigation, suggesting that the species under study is demanding in soils with good infiltration capacity, which facilitates root development.

In this sense, Torres-Torres et al. (2018a) indicate that the survival and initial growth of some forest species are influenced by the infiltration capacity of the organic substrates used in propagation; therefore, they suggest the use of combinations such as alluvial sand. This approach contrasts with what has been observed in the present research, in which it is evident that the survival of seedlings is similar in the different organic substrates used.

Taking into account the results obtained, it can be inferred that for the propagation of $H$. chrysantha the seeds should be sown (without application of pre-germination treatments) under shade using Chicken manure+ ant land in proportion 2:1. Once germinated the seeds, the seedlings must be placed to free exposure, using the same substrate in which the seeds germinated. Under these conditions the best results of germination, height growth and survival are obtained.

\section{ACKNOWLEDGEMENTS}

The authors thank COLCIENCIAS for funding this research, the Universidad Tecnológica del Chocó, Colombia for logistical support, and the members of the Salero community for their accompaniment during the field phase.

\section{ETHICS, CONFLICT OF INTEREST, AND FUNDING STATEMENT}

Authors declare that they have complied with all relevant ethical and legal requirements, both during the study and in the manuscript; that there are no conflicts of interest of any kind; and that all funding sources are fully and clearly detailed in the acknowledgements section. They also agree with the final edited version of the document. The respective signed legal document is in the archives of the journal.

The declaration of the contribution of each author to the manuscript is as follows: H.H.M.A: Coordination in the information gathering, initial writing of the document (introduction, results), J.J.T.T.: Manuscript structuring (assembly of each author's contribution), discussion writing, part of the introduction and translation of the article, C.A.P.P.: Part of the project formulation team, 
support in data collection, writing of the methodology, B.A.R.B.: Statistical analysis and experimental design, M.M.G. a: Support in the interpretation of the results and final conclusions, and L.R.M.: contribution to data collection

\section{REFERENCES}

Aguirre, N., Günter, S., \& Stimm, B. (2008). Mejoramiento de la propagación de especies forestales nativas del bosque montano en el Sur del Ecuador. Revista Científica Universitaria, 8(1), 57-66. Retrieved from https://www.researchgate.net/publication/259622802_Mejoramiento_de_la_propagacion_de_especies_fores tales_nativas_del_bosque_montano_en_el_Sur_del_Ecuador

Alcaldía municipal de Unión Panamericana. (2016). Plan de desarrollo del municipio de Unión Panamericana 2016-2019: Construyendo bienestar. Retrieved from http://unionpanamericanachoco.micolombiadigital.gov.co/sites/unionpanamericanachoco/content/files/0000 81/4015_pdtunionpanamericana20162019.pdf

Blaser, J., \& Thompson, I. (2010). Summary Paper on Sustainable Forest Management. Nueva York, USA: Partnership for Cooperation on Forests.

Cordero, J., Mesén, F., Montero, M., Stewart, J., Boshier, D., Chamberlain, J., Penníngton, T., Hands, M., Hughes, C., \& Detlefsen, G. (2003). Descripciones de especies de árboles nativos de América Central. In J. Cordero \& D. H. Boshier (Eds.). Árboles de Centroamérica: un manual para extensionistas (pp. 311-958). Turrialba, Costa Rica: Centro Agronómico Tropical de Investigación y Enseñanza (CATIE).

Klínger, W., Roa, R., Ibargüen, T., Rengifo, O., Barcos, R., Mosquera, H., \& Perea J. A. (2011). Estado de las especies forestales amenazadas. In W. Klínger, G. Ramírez, \& J. M. Guerra (Eds.). Aportes al conocimiento de los ecosistemas estratégicos y las especies de interés especial del Chocó biogeográfico parte I (pp. 92-117). Cali: Instituto de Investigaciones Ambientales del Pacífico (IIAP).

Martínez, M., Torres-Torres, J. J., \& Medina, H. H. (2015). Aprovechamiento forestal maderable en cuatro municipios del departamento de Chocó, Colombia. Revista de Investigación Agraria y Ambiental, 6(2), 57-74.

Mena, V. E., Andrade, H. J., \& Torres-Torres, J. J. (2020). Composición florística, estructura y diversidad del bosque pluvial tropical de la subcuenca del río Munguidó, Quibdó, Chocó, Colombia. Entramado, 16(1), 204-215. DOI: 10.18041/1900-3803/entramado.1.6109

Mosquera, D. E., Medina, H. H., \& Martínez, M. (2012). Diversidad florística y análisis estructural de un ecosistema boscoso en el departamento del Chocó, Colombia. Revista Investigación, Biodiversidad y Desarrollo, 31(1), 19-30. DOI: 10.18636/ribd.v31i1.270

Myers N., Mittermeier, R. A., Mittermeier, C. G., Da Fonseca, G. A., \& Kent, J. (2000). Biodiversity hotspots for conservation priorities. Nature, 403, 853-858. DOI: 10.1038/35002501

Palacios, L. Y., Perea, K., Bellido, D. M., Caicedo, H. Y., \& Abadía, D. (2017) Estructura poblacional de ocho especies maderables amenazadas en el departamento del Chocó-Colombia. UNED Research Journal, 9(1), 107-114. DOI: 10.22458/urj.v9i1.1685

Pinilla, H., Medina, H. H., Torres-Torres, J. J., Córdoba, E., Córdoba, J. C., Mosquera, Y., \& Martínez, M. (2016). Propagación y crecimiento inicial del abarco (Cariniana pyriformis Miers), utilizando semillas silvestres. Revista de Investigación Agraria y Ambiental, 7(2), 87-79. DOI: 10.22490/21456453.1559 
Rengifo, L. \& Torres-Torres, J. J. (2016). Manejo en vivero de Hymenaea courbaril L. (Fabaceae) en el municipio de Unión Panamericana, Chocó, Colombia. Revista Investigación Biodiversidad y Desarrollo, 35(1), 11-19. DOI: 10.18636/riutch.v35i1.812

Rivera, L., Peñuela, M., Jiménez, E. \& Vargas, M. (2013). Ecología y silvicultura de especies útiles amazónicas. Leticia: Universidad Nacional de Colombia. Retrieved from http://www.bdigital.unal.edu.co/36632/6/9789587616347.pdf

Román, F., De Liones, R., Sautu, A., Deago, J., \& Hall, J. S. (2012). Guía para la propagación de 120 especies de árboles nativos de Panamá y el neotrópico. New Haven: Environmental Leadership and Training Initiative (ELTI).

STRI (Instituto Smithsonian de Investigaciones Tropicales). (2013). El árbol Guayacán Tabebuia Chrysantha. New Haven: Yale School of Forestry \& Environmental Studies.

Suárez, D., \& Melgarejo L. M. (2010). Biología y germinación de semillas. In L. M. Melgarejo (Ed.). Experimentos en fisiología vegetal (pp. 13-25). Bogotá, Colombia: Universidad Nacional de Colombia.

Torres-Torres, J. J., Mena, V. E., \& Álvarez, E. (2016). Composición y diversidad florística de tres bosques húmedos tropicales de edades diferentes, en el Jardín Botánico del Pacífico, municipio de Bahía Solano, Chocó, Colombia. Revista Biodiversidad Neotropical, 6(1), 12-21. DOI: 10.18636/bioneotropical.v6i1.197

Torres-Torres, J. J., Mena, V. E., \& Álvarez, E. (2017). Carbono aéreo almacenado en tres bosques del Jardín Botánico del Pacífico, Chocó, Colombia. Entramado, 13(1), 200-209. DOI: 10.18041/entramado.2017v13n1.25110

Torres-Torres, J. J., Medina, H. H., Pinilla, H., Córdoba, E., \& Martínez, M. (2017). Propagación en vivero de la especie forestal Dipteryx oleifera Benth mediante semillas. Revista Politécnica, 13(24), 19-26. Retrieved from https://revistas.elpoli.edu.co/index.php/pol/article/view/1087

Torres-Torres, J. J., Medina, H. H., \& Martínez, M. (2018a). Germinación de semillas silvestres de Apeiba glabra Aubl. (Malvaceae) y crecimiento inicial de plantas. Revista Corpoica Ciencia y Tecnología Agropecuaria, 19(2), 323335. DOI: 10.21930/rcta.vol19num2art:750

Torres-Torres, J. J., Medina, H. H., \& Martínez, M. (2018b). Germinación y crecimiento inicial de Cedrela odorata L. (Sapindales: Meliaceae), empleando semillas silvestres en el departamento del Chocó, Colombia. Revista Biodiversidad Neotropical, 8(1), 22-28. DOI: 10.18636/bioneotropical.v8i1.741

Torres-Torres, J. J., Medina, H. H., \& Martínez, M. (2018c). Germinación y crecimiento inicial de Hymenaea oblongifolia Huber en el municipio de Istmina, Chocó, Colombia. Entramado, 14(2), 230-242. DOI: 10.18041/19003803/entramado.2.4760

Trujillo, E. (1995). Algunos reportes de almacenamiento y tratamientos pregerminativos de semillas forestales. In R. Salazar. (ed.). Avances de la producción de semillas forestales en América Latina: Memorias del simposio. (pp. 317-327). Managua, Nicaragua: CATIE. Retrieved from http://www.scielo.org.mx/pdf/remcf/v6n30/v6n30a5.pdf

Varela, S., \& Arana, V. (2011). Latencia y germinación de semillas: Tratamientos pregerminativos. 3 ed. Bariloche, Argentina: INTA EEA. Retrieved from https://inta.gob.ar/sites/default/files/script-tmp-inta_latencia.pdf 